\title{
Innovation Strategy of Rural Financial Management Under the Background of Rural Revitalization
}

\author{
Sun Yu-Qing \\ School of Accounting, Jiaozuo University, Jiaozuo, Henan, China
}

\begin{abstract}
:
In the new era, rural financial management is an important basic work in rural areas. It is of great significance to safeguard the interests of farmers and promote the healthy development of rural collective economy. This paper first analyzes the main financial management mode in rural areas of China and points out the main problems. Then this paper puts forward the effective strategies to realize the innovation of financial management mode. This paper expounds the basic types of China's rural financial management mode, and puts forward the informatization strategy of rural financial management. Finally, in view of the problems of rural financial informatization construction in China, this paper puts forward specific development measures and methods from three aspects: implementing network system to improve rural financial informatization operation platform, innovating village level accounting agency service operation mode, and cultivating humanistic environment to adapt to the development of rural financial informatization, and summarizes the construction content. The experimental data show that the method can improve the effectiveness and efficiency of rural financial management.
\end{abstract}

Keywords: Rural Financial Management, Collective Economy, Financial Management Mode, Agent Service Operation Mode.

\section{INTRODUCTION}

At the end of the 20th century, in order to better solve the financial contradictions in rural areas, the relevant departments of the state proposed to implement financial informatization in rural areas, which can not be realized due to various reasons [1-2]. Since the beginning of the 21st century, the development of computer and communication technology, the construction of information network, make the rapid development of information technology in our country, in the vast rural construction and implementation of modern financial information management, to solve the severe financial contradictions in rural areas, then there are feasible conditions. In order to promote the informatization of rural finance [3-4], the Ministry of agriculture has successively issued the "opinions on gradually promoting the work of agricultural economic Computerization", "reply on agreeing to list Jilin Province as the national pilot province of rural operation and management computerization" and other documents, actively promoting the national rural construction and the financial informatization management system suitable for the new rural construction. Since then, under the guidance of the Ministry of agriculture, provinces and cities have gradually implemented the information management of rural finance according to local conditions [5].

The construction of rural financial informatization is a reform and innovation of modern rural development. It is a strategic step in the process of improving the work efficiency of grass-roots 
government, solving rural contradictions, promoting rural economic development and building a harmonious socialist new countryside.

\section{THE ROLE OF RURAL FINANCIAL INFORMATION}

2.1 The meaning of financial accounting informatization

Financial accounting informatization is the organic combination of financial accounting and modern information technology to innovate accounting theory and practice in all aspects, so as to establish a financial information management system to meet the needs of modern economic management. In 1954, the United States General Electric Company used the computer to calculate the salary of employees, which opened the prelude of the human use of computer for financial data processing [6-7]. Later, there appeared accounting computerization, MRPII and other business management processes reflecting the idea of informatization [8]. Until April 12, 1990, Gartner put forward "ERP" for the first time in "ERP: vision of the next generation of MRPII" [9]. This kind of enterprise management oriented information resource management scheme immediately aroused great interest of financial executives and finance professors. Many CEOs of multinational enterprises rush to set up ERP projects, which completely leads to the war of modern information technology bombing the traditional financial management mode, and makes accounting informatization rapidly become the highest palace of enterprise financial management.

In China, financial accounting informatization has experienced a similar development process. Since the pilot work of computer application in financial accounting was carried out in Changchun No.1 Automobile factory in 1979, the financial accounting information market of all walks of life has exceeded more than 3 billion, and the domestic financial accounting information has experienced a leap forward development in 20 years [10]. According to the statistics of relevant departments, the scale of China's financial accounting information market in 2010 was nearly 7 billion yuan. The times have created heroes. The leaping market has also bred financial accounting informatization developers with amazing growth rate. National enterprises such as UFIDA, Kingdee, Inspur, new China University and abacus also take advantage of the east wind of informatization, and even dare to compete with SAP, Oracle and other international giants. According to statistics, domestic financial information software has occupied more than $80 \%$ of the national market share in 2010 .

2.2 The role of rural financial informatization

1) It is conducive to the standardization of rural financial work

The implementation of financial accounting informatization requires financial personnel to carry out standardized and standardized operation in strict accordance with the process and requirements determined by financial software, which objectively solves the problems of non-standard and easy omission in traditional manual operation.

Therefore, the implementation of financial accounting informatization in rural areas, one is to standardize rural financial accounting. For a long time, due to the vast rural area, uneven economic development, non-uniform, non-standard rural financial accounting work is widespread. We use the characteristics of financial information, through the government to formulate unified and standardized data entry requirements and design automatic and standardized financial software processing process to change this phenomenon. Second, we can regulate financial behavior. The application of financial software provides the operation authority for the operators of various business work, and the managers must complete each work according to the standardized operation process, so as to standardize the procedures. 
Third, standardize the management behavior and effectively avoid ultra vires operation. After the implementation of information management, due to various economic management matters are reflected through the computer system, financial software requires leaders to establish a reasonable division of labor responsibility system and mutual restraint system, so as to effectively curb the ultra vires and corruption of managers. The fourth is to standardize the preservation and management of rural accounting archives, to prevent deception and embezzlement of farmers.

2) It is conducive to improving work efficiency and reducing the financial burden of the government

Before the implementation of rural financial informatization, the processing of financial data mostly relies on manual operation. The efficiency of financial data processing is high, with many errors and heavy workload. There are too many grass-roots financial personnel. There are not a few people who "eat imperial grain", and the government has a heavy burden. After realizing the financial accounting information, the financial personnel only need to input the audited accounting data into the computer according to the regulations, and the computer can automatically, efficiently and accurately complete the data sorting, processing, transmission, storage, output and other work. It makes financial personnel free from heavy bookkeeping, accounting and reporting, greatly improving the work efficiency, making village accounting can also serve as custody, secretarial and other functions, so that the government can reduce the basic financial personnel and reduce financial burden.

3) It is conducive to the openness of rural government affairs, increase the transparency of rural finance, and let farmers rest assured, so as to reduce the contradiction between cadres and the masses

After the rural financial informatization, the financial status and operating results of the rural collective can be input into the computer on time every month after being audited by the accounting professionals, and the relevant accounting information will be automatically generated by the computer. It can be used by villagers to find out the accounting information closely related to them. Make our finance more transparent and closer to the ordinary people. If the villagers want to know the financial situation of the village, they can go to the relevant government affairs open online inquiry, so that "the masses understand, and the cadres are innocent."Table 1 shows the financial indicators.

Table 1 Financial indicators

\begin{tabular}{|c|c|c|c|}
\hline Category & Name & Number & Formula \\
\hline \multirow{4}{*}{$\begin{array}{c}\text { Profitability } \\
\text { indicators }\end{array}$} & Net sale profit & I11 & Net sale profit / Sales revenue \\
\cline { 2 - 4 } & The total assets yield & I12 & Net sale profit / Total assets \\
\cline { 2 - 4 } & Return on equity & I13 & Net sale profit / Net assets \\
\cline { 2 - 4 } & $\begin{array}{c}\text { Retained earnings to } \\
\text { total assets ratio }\end{array}$ & I14 & $\begin{array}{c}\text { Undistributed profit / Total } \\
\text { assets }\end{array}$ \\
\hline \multirow{3}{*}{ Solvency indicators } & Gearing ratio & I21 & Total liabilities / total assets \\
\cline { 2 - 4 } & Interest coverage ratio & I22 & $\begin{array}{c}\text { (Net income + interest expenses } \\
\text { + income) / Interest expense }\end{array}$ \\
\hline
\end{tabular}

\section{THE CURRENT SITUATION AND PROBLEMS OF RURAL FINANCIAL INFORMATION DEVELOPMENT IN CHINA}

3.1 Present situation of rural financial informationization in China

It has been more than ten years since our government put forward the implementation of rural financial informationization, which has achieved certain results. According to the latest statistical survey data, there 
are 41,287 townships, street offices and neighborhood committees in China, and there are more than 600,000 administrative village organizations. The GDP created by rural economic organizations owned by these administrative villages accounts for more than $46 \%$ of the total GDP. Therefore, the financial information management of rural economic organizations has been paid more and more attention by the national government departments. With the wide application of financial information in all walks of life, up to now, more than $60 \%$ of the county-level financial management departments in China have applied trust management. However, the proportion of financial application informationization in rural economic organizations has reached nearly $10 \%$, mostly concentrated in the southeast coast, Yangtze River basin, Beijing-Tianjin-Tangshan and other developed areas. However, with the rapid development of rural economy, rural financial informationization has also spread rapidly to western China.

3.2 Problems in the Development of Rural Financial Informatization in China

1) One of the basic conditions of rural financial informatization is imperfect infrastructure

Rural financial information is the use of modern information technology to participate in rural accounting affairs, and the most basic use of modern information technology is to be equipped with computer hardware facilities, such as computers, printers, memory cards and other hardware. In addition, due to the need to ensure the continuity of accounting work, to prevent the computer from interruption due to power failure and other reasons, resulting in the loss of accounting data, UPS should also be equipped to ensure the safe operation of the computer. Due to the unbalanced development of regional economy in China, there is a serious imbalance in the choice and purchase of computer and other hardware facilities in the development of financial accounting informatization in rural areas, which hinders the popularization of financial accounting informatization in rural areas.

At the same time, according to the business needs of enterprises to be included in financial sharing, the positions of capital operation, operation management, file management, Accounting Director, material accounting, cooperative construction accounting, ship machinery accounting, expense accounting, salary accounting, audit, income accounting, tax accounting and reporting are set up according to the business scope, as shown in Figure 1.

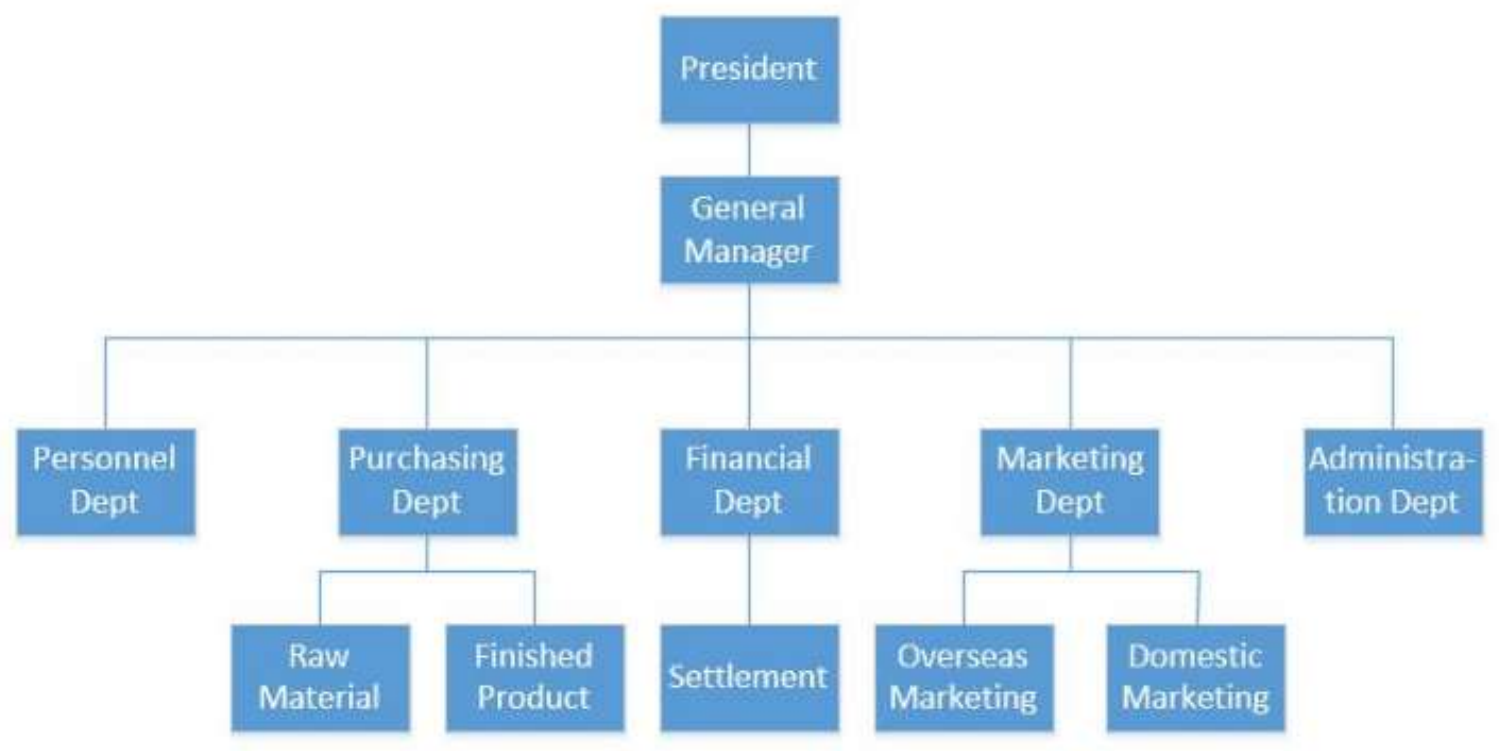

Fig 1: Organization chart of Z Enterprise Financial Sharing Center 
2) China's rural financial information in the supporting software is not perfect

In addition to the hardware, supporting accounting software is also essential. Accounting software is a software system which is based on accounting theory and accounting method, accounting standards and accounting system, computer and its application technology as means, accounting data as processing object, providing information for accounting, financial management and other management of units as the goal, and applying computer technology to accounting work. Including computer programs, stored data and related information. For example, accounting processing software, in addition to the command computer accounting processing procedures, basic data (accounting subjects, vouchers, etc.), also includes software manuals and other relevant technical information, to guide users to operate.

3) The low cognitive level of rural farmers restricts the development of rural financial informatization

Although China has put forward that "science and technology is the first productivity" for many years, it is still serious to despise the atmosphere of science education in the vast countryside. Especially in the embarrassing stage of modern education, more rural children can not complete the compulsory education for nine years directly. How can we apply modern management methods and scientific management tools to effective financial management. The low quality of science and technology of rural labor force has become an important factor restricting the promotion of rural financial informatization.

\section{SPECIFIC MEASURES TO PROMOTE THE CONSTRUCTION OF RURAL FINANCIAL INFORMATION IN CHINA}

4.1 Implement network system to improve the rural financial information operation platform

1) Planning and improving the infrastructure of information system

Information hardware facilities are the material basis for realizing information. Different economic organizations should plan the purchase plan of hardware equipment according to their future development goals, economic strength, management requirements and other factors, and make a principled plan for computer hardware grade, network structure and other external equipment, so as to make reasonable longterm arrangements and avoid resource waste. The purpose of rural financial informatization is to promote the effective development of rural financial informatization, follow the principle of unified and sustainable development, and reasonably plan the hardware facilities. The principle of unification is to make the standard of hardware equipment planning under the guidance of the government, and the principle of sustainable development is to select uniform, high-performance and high-tech server configuration, client configuration, storage device, backup device, etc. within a certain range to meet the future development needs of the agricultural sector. And because the rural financial information is a huge information system, we should try our best to make the hardware facilities more compatible, more reliable and easier to maintain.

2) Develop computer software suitable for rural financial information

Facing the problems of poor adaptability, poor universality, low technology content, poor operability and low popularization rate of current village accounting software. We should innovate the system development mechanism and develop the special financial accounting information application software for the vast rural and farmers, taking into account the unique characteristics of rural collective economic organizations in financing channels, asset operation, income distribution and financial information management. The computer software is integrated with the functions of financial management, financing cost analysis, asset operation decision, income distribution, financial supervision, financial disclosure, 
government affairs publicity, etc.

In view of this, the government finance department can carefully organize and entrust some software development companies with perfect qualification, strong technical strength and complete service system to develop a general accounting information system which is guided by rural accounting demand, advanced management thought, advanced technical framework, strong expansibility, easy resource integration and easy operation. Although such initial investment cost will be great, such software developers develop high software technology gold content, high service guarantee coefficient in the later period, and unified planning by government management departments can effectively reduce the cost of the overall project. Figure 2 shows scree plot of each factor.

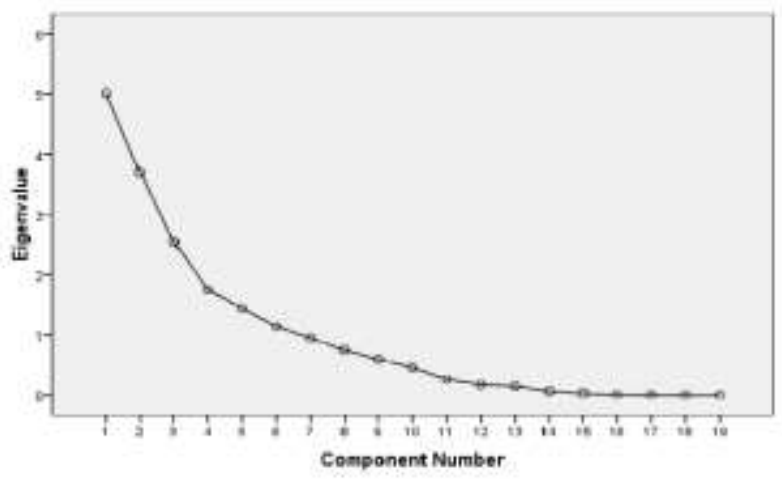

Fig 2: Scree Plot of Each Factor

4.2 Improve the human environment to adapt to the development of rural financial information

It is necessary to emancipate the mind, re-establish the correct value orientation, and cultivate "four understanding" talents to cultivate the humanistic environment to adapt to the development of rural financial informatization.

1) Improve the environment of consciousness and establish the sense of master

In view of the two sides of the traditional concepts of "rule by doing nothing", "the golden mean" and "harmony is precious" in rural areas for a long time, we should increase the strength of selecting excellent college students to be village officials in rural areas, and input new blood into rural areas. Young college students have knowledge, ideals, enthusiasm and dare to take responsibility. After this new blood flows into the countryside, although it can't fundamentally change the two sides of Confucianism and Taoism in China for thousands of years, it will certainly give the farmers a new sense to some extent. "A single spark can start a prairie fire", let this kind of blood penetrate into the countryside, imperceptibly influence the countryside and the surrounding farmers, let the farmers emancipate their minds and oppose the consciousness of the master.

2) Improve the training environment of rural financial information talents

Rural financial information system itself is a combination of computer technology, modern transmission technology, database technology, agricultural economy, financial management and other knowledge and skills. Qualified financial information talents are the key to the construction of rural financial information, and the lack of talents will inevitably lead to the failure of rural financial information construction. Government departments and their relevant management departments should closely cooperate with each other and devote themselves to the training of rural specialized information personnel, so as to cultivate a large number of "four understanding" talents who understand information technology, 
agriculture, economy and finance. Government is governed by talents, and industry prospers by talents. The talents with "four understandings" are the important foundation for the construction of rural financial informatization. In the construction of rural financial informatization, we must pay attention to the construction of rural accounting agent service staff.

\section{CONCLUSION}

The construction of rural financial information involves many aspects and related factors. It is a very complex system engineering, which is the highest stage of rural financial development recognized by human beings. How to promote the comprehensive development of rural financial information in the practical application, and realize the smooth financial information of modern new countryside is the key research direction in the future, especially to reflect the rural financial information timely and comprehensively, and to be used by rural financial information users at all levels is the main problem to be solved in the future.

As China's agricultural informatization has just entered the stage of development, and the research on rural financial informatization is still in its infancy, there are few statistical data and information about the development of rural financial informatization. In addition, my knowledge background and the lack of relevant information, the research on this topic is only at the primary stage, many problems need to be further studied. Secondly, due to the use of different disciplines of theory and method to study the construction of socialist new rural informatization, there may still be immature places in theory, method and concept, which need to be further deepened.

\section{REFERENCES}

[1] Wang Huacheng. Financial Management Hypothesis. Accounting Research, 1999

[2] Gu Qi, Yu Dongzhi. Theoretical Analysis of Eva Financial Management System. Accounting Research, 2000 (11): $31-36$

[3] Liang Tongying, Chen Guangbing. Innovative Thinking on Financial Management Mode of Small and Medium-sized Enterprises Under Network Environment. Accounting Research, 2003 (05): 50-54

[4] Wang Qingcheng, Sun Maozhu. a Review of Some Theoretical Viewpoints on Recent Financial Management in China. Accounting Research, 2003, 6: 40-43

[5] Wang Huacheng, Tong Yan. Review and Prospect of Financial Management Theory Research -- a Review of China's Financial Theory Research in the Last 20 Years of the 20th Century. Accounting Research, 2001 (12): $37-45$

[6] Lu Zhengfei. on Enterprise Group and Centralization of Financial Management. Accounting Communication, 2000, 000 (009): 4-6

[7] Wang Qingcheng. Reflections on Financial Management Objectives. Accounting Research, 1999, 000 (010): $32-36$

[8] Luo Fei, Wang Zhuquan. on the Financial Management of State-owned Enterprises As Investors. Accounting Research, 2001 (04): 3-9

[9] Liu Shulian. Several Issues on the Construction and Implementation of Financial Management Curriculum. Accounting Research, 2005 (12): 36-41

[10] Shi Xiuqing. "Campus Card" and Information Construction of Financial Management in Colleges and Universities. Journal of Shanxi University of Finance and Economics, 2006 (s2): 152-153 